\title{
INFORMATION TECHONOLOGY AND LIFELONG EDUCATION - IMPLICATIONS ON THE EU EMPLOYED POPULATION
}

\author{
Laura Timiras \\ "Vasile Alecsandri" University of Bacău \\ lauratimiras@yahoo.com
}

\begin{abstract}
The quality and the skills of human resources are important factors in the success of every organization wherever it act. Moreover this is really true in a very competitive market such as European Union. In the European Union the number of persons who are taking part in high education studies after the age of 25 years has seen an upward trend in recent years, increasing thus the share of employed graduates of tertiary education in total employment over 25 years. This increase is generated by the access to education forms adapted in terms of time and location of training. The appearance and development of these forms can be explained by the use of information technology (Internet access). Statistics show that in the EU, household access to the Internet and its frequency of use was also increasing, approximately $80 \%$ of all persons aged 16 to 74 years have ever used this information and communication tool.
\end{abstract}

\section{Keywords}

tertiary education; students; employed population; information technology; Internet access

\section{JEL Classification}

M30

\section{Objectives}

Today, the problem of employment of EU population is quite a debated subject. The most evident problems relate to youngest category of population, that of young people under 25, but equally to employees over this age.

In this quite problematic context of labor market, this article aims to take a picture of the evolution of the lifelong learning process of EU population, especially of those employed. We concentrate on the case of tertiary education in the context of the development and expansion of information technology. Accordingly, it is intended to highlight the extent to which the EU population, and especially the employed population aged 25 years followed a higher education degree as a consequence of the emergence and development of forms of part-time learning, which is much more suited to people who want flexibility in terms of time organization and choice of training location.

It has been also aimed to highlight any differences between EU member states in terms of the intensity with which the lifelong training phenomenon manifests among the employed population, namely the existence of association between the intensity of its manifestation and public access to the Internet.

\section{Literature review}

Since the early 70s, global academic promote the idea of the informal education approach, without proposing substantial changes in the formal process. New form of learning was perceived as an element of complementarity, which have the capacity to 
provide those interested with the knowledge and skills to adapt to a changing environment (Sharples, 2000). It's essentially, as highlighted by Benteley in 1998, a long-term approach through which individuals become their own managers in an informal learning process.

The process of assimilation and integration of information technology in education has been the subject of numerous processes initiated at EU level.

European Union's interest toward the creation of a modern education environment has seen its peak in June 2002, while promoting eEurope initiative, announcing the transition to the knowledge economy. The use of information technology in formal educational processes aimed at achieving EU objectives as follows: improving curricula, educational sustainable development of educational resources in the online environment, creating and developing e-learning platforms, promoting formal continued education etc.

The approach initiated by the European Union in creating a knowledge-based economy continued in 2005 under the initiative "i2010 - A European Information Society for growth and employment'”, context in which it has been promoted as fundamental sustainable economic factors two key concepts: information and innovation.

The year 2009 brought to the forefront a new document - ET 2020 Strategic Framework for European Cooperation in Education and Professional Training (Council Of The European Union, 2009) - which promote the impact of education process on the basis of information technology over the economies of EU members. Particular attention was given in this document to promoting the access to adult education through concept of "lifelong learning".

The concept of "lifelong learning" enjoys a wide interest among specialists in the field, both in academia and in practice. According to the EU, Life Long Learning is a continuous training approach involving action at three levels: initial training, ongoing training and continued education". Taking into consideration the target of the new concept, namely those over 25 years old, Knapper and Cropley mentioned individual dimension of the concept, namely "planning own learning methods depending on availability and personal motivations" (Knapper C. and Cropley, 2000)

According to the specialists the concept of "lifelong learning" can be operationalized through various methods, from traditional classroom "face to face" type to different forms incorporating information technology - distance learning, joint education and elearning. As can be seen, distance learning, being directly correlated with the integration of the technology into the educational process, is a part of lifelong learning concept, this idea being supported by numerous specialists in the field (Bates, 1999; Garrison, 1999; Niper, 1989; Peters, 2001; Kose, 2010). It should be noted, however, that between distance education and e-learning there is a number of differences, which are extremely important in the context of the proposed analysis, as follows:

- distance learning, which appeared according to Bell and Tight in the midnineteenth century, involves the physical separation of the person trained to the trainer at certain stages of educational process (Bell and Tight, 1993]. On the other hand, e-learning is a concept of the twentieth century, involving the use of information technology to achieve a wide range of educational objectives, ranging from its integration in the traditional process training to one exclusively online environment.

- the target of distance education is the adults who have "family responsibilities and limited time" (Peters, 2001). On the other hand, the target in e-learning education is extensive, targeting formal process, from primary education up to the postgraduate education.

- global and European theory and practice shows much higher costs for e-learning education versus the distance learning (Bates, 2001; Ryan, 2002). 
Major differences between the two forms of learning can be observed in the Member States of the European Union according to the level of economic development, the development of the education system, the acceptance shown by the population to new and so on. In Romania compared to other EU countries concentration can be observed in the form of distance learning at the expense of e-learning.

In other words, the analyzed concept - lifelong learning captures a society in which many levers are operationalized in the scope of learning for all ages. According to the opinions of various authors (Aspin and Chapman, 2000; Fischer, 2001) learning process is not limited to formal institutions, but it extends to all areas of activity of individuals (work, home, etc.).

Beyond the simple definition of the concept of lifelong learning, academic raises numerous questions to identify the results of this process, namely: What is the connection between this approach and formal learning process? What are its results and how can these be quantified? and so on.

It seems that although academia has no big problems in defining the concept, barriers arise when quantifying results generated by it. Even if the desired results have been identified - the assimilation of knowledge, skills and capabilities - it seems that it is more difficult to quantify the assimilation manner of lifelong learning. In this respect, two British authors (Jiusto and DiBiasio, 2006) noted that the process of lifelong lerning cannot be measured until the person has passed all stages of life that involves the acquisition of knowledge and skills. In the same direction of the identification of the results of lifelong learning may be mentioned the article proposed by Klamm et al. (2007), according to whom the concept captures "openness to learning opportunities, a process that involves initiative and independence in the acquisition of knowledge, responsibility, creativity, long term orientation and ability to use problem-solving skills.

\section{Research methodology}

The work is a study based on secondary data sources from Eurostat. We used in our analysis structure indicators and time series indicators which have revealed the evolution of tertiary education process throughout the life in the EU countries and the EU population access to information technologies, namely the frequency of Internet use.

According to the Eurostat methodology the people included in the lifelong training is those with age between 25 and 64 years. Not having data on tertiary education for this age group, we considered in highlighting the intensity of lifelong education the students over 25 years old and working population of 25-74 years.

According to ISCED - International Standard Classification of Education - UNESCO 1997, tertiary education includes level 5, namely higher education, and level 6, namely postgraduate education (taken after www.insse.ro). Regardless of the time of accession to the EU of different countries, the indicators used in this analysis were aggregated for all the years covered by the study for all 28 present states.

\section{Research results}

In EU countries there has been a rapid expansion of public access to the Internet, coupled with increased utilization of it. Thus, according to Eurostat data, at the EU countries (except Croatia) from 2005 to 2013, the share of households with Internet access increased from $48 \%$ to $79 \%$, mainly due to strong increases registered in the new EU states. Closely related to access to the Internet, its usage has grown, so the share of persons with age between 16 and 74 years who have ever used the Internet 
has gone from $60 \%$ to $79 \%$ in the indicated period. Bothe in the case of Internet access in households and in terms of the intensity of its use, the old EU countries stand largely above average throughout the considered period. On the other hand, the largest increases were recorded in the States belonging to the former communist bloc.

Table 1 Household access to the Internet and Internet use in the EU

\begin{tabular}{|c|c|c|c|c|c|c|}
\hline \multirow[t]{2}{*}{ Countries } & \multicolumn{3}{|c|}{$\begin{array}{l}\text { Households with Internet access - } \\
\text { Percentage of households }\end{array}$} & \multicolumn{3}{|c|}{$\begin{array}{l}\text { Individuals who have ever used } \\
\text { the Internet - Percentage of } \\
\text { individuals* }\end{array}$} \\
\hline & 2005 & 2010 & 2013 & 2005 & 2010 & 2013 \\
\hline Belgium & 50 & 73 & 80 & 61 & 81 & 84 \\
\hline Bulgaria & n.d. & 33 & 54 & n.d. & 49 & 59 \\
\hline Czech Republic & 19 & 61 & 73 & 37 & 72 & 80 \\
\hline Denmark & 75 & 86 & 93 & 86 & 90 & 96 \\
\hline Germany & 62 & 82 & 88 & 71 & 83 & 87 \\
\hline Estonia & 39 & 68 & 80 & 64 & 78 & 84 \\
\hline Ireland & 47 & 72 & 82 & 45 & 73 & 82 \\
\hline Greece & 22 & 46 & 56 & 27 & 48 & 64 \\
\hline Spain & 36 & 59 & 70 & 50 & 68 & 76 \\
\hline France & n.d. & 74 & 82 & n.d. & 80 & 86 \\
\hline Croatia & n.d. & 56 & 65 & n.d. & 58 & 71 \\
\hline Italy & 39 & 59 & 69 & n.d. & 56 & 64 \\
\hline Cyprus & 32 & 54 & 65 & 36 & 55 & 68 \\
\hline Latvia & 31 & 60 & 72 & 49 & 71 & 78 \\
\hline Lithuania & 16 & 61 & 65 & 39 & 65 & 71 \\
\hline Luxembourg & 65 & 90 & 94 & 71 & 92 & 95 \\
\hline Hungary & 22 & 60 & 71 & 40 & 68 & 76 \\
\hline Malta & 41 & 70 & 79 & 43 & 64 & 72 \\
\hline Netherlands & 78 & 91 & 95 & 82 & 92 & 95 \\
\hline Austria & 47 & 73 & 81 & 60 & 77 & 84 \\
\hline Poland & 30 & 63 & 72 & 42 & 65 & 68 \\
\hline Portugal & 31 & 54 & 62 & 37 & 54 & 67 \\
\hline Romania & n.d. & 42 & 58 & n.d. & 43 & 58 \\
\hline Slovenia & 48 & 68 & 76 & n.d. & 72 & 77 \\
\hline Slovakia & 23 & 67 & 78 & 58 & 83 & 85 \\
\hline Finland & 54 & 81 & 89 & 77 & 89 & 94 \\
\hline Sweden & 73 & 88 & 93 & 88 & 93 & 96 \\
\hline United Kingdom & 60 & 80 & 88 & 72 & 87 & 92 \\
\hline $\begin{array}{c}\text { European Union } \\
\text { ( } 28 \text { countries) }\end{array}$ & n.d. & 70 & 79 & n.d. & 73 & 79 \\
\hline
\end{tabular}

* Refers to population between 16 and 74 years old Source: Adapted from Eurostat

Regarding the lifelong learning, it has been a positive evolution in the European Union, the number of people between 25 and 64 years old who attended some form of training (last 4 weeks, prior to survey) increasing from $7.1 \%$ in 2002 to $10,4 \%$ in 2013. The highest values were recorded in Denmark (more than $31 \%$ of the 
population between 25 and 64 years old following a training form in 2013), followed by Sweden and Finland (values around 28\% and, respectively, $25 \%$ in 2013), while the lowest values (until $2 \%$ in 2013) were registered in Bulgaria and Romania (according to Eurostat data).

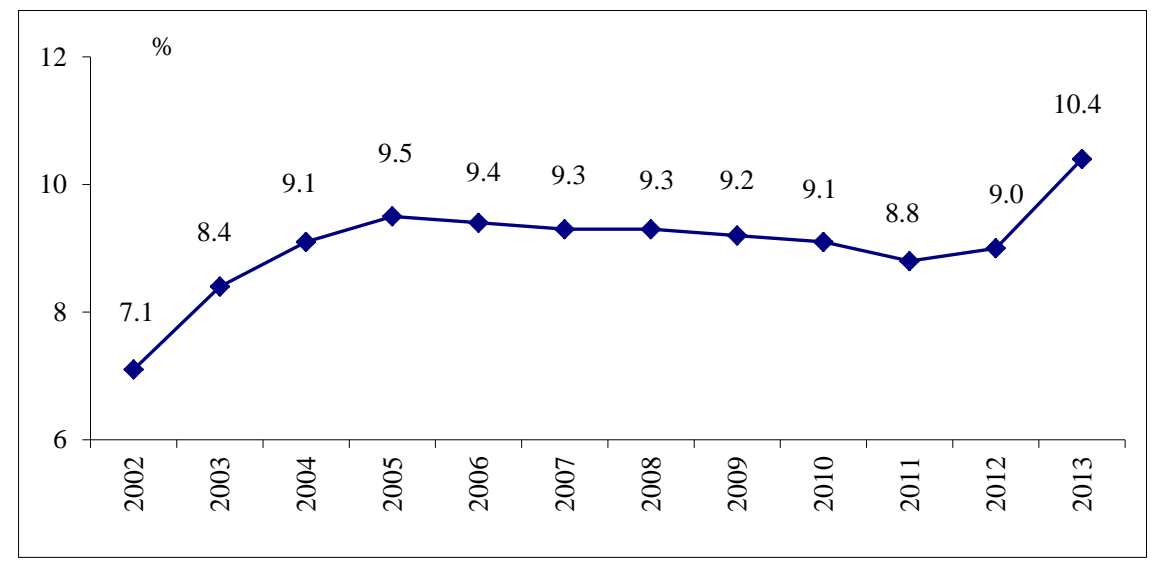

Figure 1 Participation rate in education and training (last 4 weeks) of total population between 25 and 64 years old in EU - 28 countries in 2002- 2013 Source: Adapted from Eurostat

Much more accelerated has been the evolution of higher education (levels 5 and 6 of education, ISCED classification), so from 2000 to 2012 there has been an increase in number of students over 25 years old who continue tertiary studies with more than $37,8 \%$ (at the EU, except Croatia) - a rate that exceeded the growth rate of the total number of students in tertiary education - levels 5 and 6 (respectively, 26,2\%), thus increasing the share of this age group (over 25 years) in total students number (according to Eurostat data).

Ranked first in terms of share of are: Finland, Sweden, Denmark, Austria, and, on the other hand, in France, Croatia, Poland, Belgium, Lithuania, Malta and Bulgaria there is a lowest trend for further tertiary studies after the age of 25 years.

The largest increases in this indicator (share of students over 25 years old in total number of students) were recorded in Greece, Cyprus, Slovakia, Ireland, Romania, Czech Republic, Spain and in Luxembourg, United Kingdom, Germany, Latvia, Denmark, Italy and Sweden the share of students over 25 years old in total number of students has been declining, in 2000-2012 period.

Table 2 Evolution of the number of the students over 25 years old in tertiary education - levels 5 and 6, in the EU in the period 2000 to 2012

\begin{tabular}{|c|c|c|c|c|c|}
\hline \multirow{2}{*}{ Countries } & \multirow{2}{*}{$\begin{array}{c}\text { The number of } \\
\text { students over 25 } \\
\text { years old in 2012 } \\
\text { (thousand) }\end{array}$} & \multicolumn{4}{|c|}{$\begin{array}{c}\text { The share of students over 25 } \\
\text { years old in total number of } \\
\text { students (\%) }\end{array}$} \\
\cline { 3 - 6 } & 113 & 2000 & 2005 & 2010 & 2012 \\
\hline Belgium & 81 & 23 & 23 & 23 & 24 \\
\hline Bulgaria & 144 & 20 & 33 & 33 & 28 \\
\hline Czech Republic & 148 & 57 & 63 & 56 & 54 \\
\hline Denmark & 1310 & 52 & 46 & 42 & 45 \\
\hline Germany & & & & & \\
\hline
\end{tabular}




\begin{tabular}{|c|c|c|c|c|c|}
\hline Estonia & 27 & 28 & 39 & 37 & 40 \\
\hline Ireland & 61 & 18 & 21 & 31 & 32 \\
\hline Greece & 328 & 5 & 27 & 47 & 49 \\
\hline Spain & 764 & 26 & 35 & 40 & 39 \\
\hline France & 429 & 18 & 21 & 19 & 19 \\
\hline Croatia & 35 & & 20 & 20 & 22 \\
\hline Italy & 604 & 32 & 31 & 31 & 31 \\
\hline Cyprus & 11 & 12 & 19 & 30 & 33 \\
\hline Latvia & 33 & 39 & 44 & 36 & 34 \\
\hline Lithuania & 47 & 22 & 34 & 29 & 27 \\
\hline Luxembourg & 2 & 100 & & & 41 \\
\hline Hungary & 133 & 29 & 40 & 35 & 35 \\
\hline Malta & 3 & 24 & 28 & 25 & 28 \\
\hline Netherlands & 264 & 28 & 28 & 26 & 33 \\
\hline Austria & 196 & 51 & 40 & 51 & 52 \\
\hline Poland & 450 & 22 & 21 & 21 & 22 \\
\hline Portugal & 146 & 32 & 36 & 39 & 37 \\
\hline Romania & 211 & 17 & 29 & 37 & 30 \\
\hline Slovenia & 32 & 27 & 34 & 33 & 31 \\
\hline Slovakia & 72 & 18 & 30 & 34 & 33 \\
\hline Finland & 174 & 50 & 52 & 55 & 56 \\
\hline Sweden & 248 & 56 & 58 & 56 & 55 \\
\hline United Kingdom & 956 & 45 & 46 & 41 & 38 \\
\hline $\begin{array}{l}\text { European Union (28 } \\
\text { countries) }\end{array}$ & 7024 & n.d. & 34 & 34 & 35 \\
\hline
\end{tabular}

In total for full-time and part-time employed population over 25 years old, we can see that from 2000 to 2013 there is an increase in the share of employed persons with higher education. Accordingly, the number of employed people (all ISCED, 1997) increased during the period considered by $10,1 \%$ (at the EU except Croatia), while employment in of people with higher education degree by 59,1\%, according to Eurostat data. This development shows that at least some of the employed population continued their studies along with running their own occupation, which is justified by the easy access of EU population to information technology and thus the possibility of following forms of education that not imply the presence in certain locations and certain time period.

It stands out the old Member States in terms of the share of people with higher education in total employment, the majority of these countries recording values above the EU average.

The first places are occupied by Malta, Poland, Portugal, Luxembourg, Romania and Ireland, this with the largest increases of noted indicator (share of employed persons with higher education in total employed population of 25-74 years) between 2000 and 2013.

Comparing the evolution of the employed population with higher education in total population, and changes in the share of households with Internet access in the countries analyzed (for the period 2005 to 2013), it appears that in most countries that have known values above the EU average of one of the indicators were recorded values above average for the second the indicator. Thus, Lithuania, Czech Republic, 
Slovakia, Greece, Poland, Latvia, Portugal, Malta, Cyprus, Ireland and Italy showed values above the EU average in terms of both indicators. On the other hand, in Denmark, the Netherlands, Belgium and Germany both indicators were below the EU average.

Table 3 Evolution of Full-time and part-time employment for 25-74 year old population levels 5 and 6 graduate education in the EU between 2000 and 2013

\begin{tabular}{|c|c|c|c|c|c|}
\hline \multirow[t]{2}{*}{ Countries } & \multirow{2}{*}{$\begin{array}{l}\text { Full-time and part-time } \\
\text { employment for } 25-74 \\
\text { year old population levels } \\
5 \text { and } 6 \text { graduate education } \\
\text { in } 2013 \text { (thousands) }\end{array}$} & \multicolumn{4}{|c|}{$\begin{array}{c}\text { Share of full-time and part-time employment } \\
\text { levels } 5 \text { and } 6 \text { graduate education in total } \\
\text { employment (all ISCED } 1997 \text { levels) of 25-74 } \\
\text { years (\%) }\end{array}$} \\
\hline & & 2000 & 2005 & 2010 & 2013 \\
\hline Belgium & $1,786.20$ & 34.2 & 38.0 & 41.8 & 42.5 \\
\hline Bulgaria & 866.1 & 24.0 & 27.2 & 28.7 & 31.3 \\
\hline Czech Republic & $1,071.00$ & 13.8 & 15.4 & 19.2 & 23.1 \\
\hline Denmark & 872.1 & 28.4 & 36.6 & 35.8 & 37.8 \\
\hline Germany & $11,546.90$ & 27.1 & 29.0 & 30.5 & 31.9 \\
\hline Estonia & 240.3 & 34.8 & 37.8 & 40.4 & n.d. \\
\hline Ireland & 813 & 26.0 & 33.3 & 43.6 & 47.3 \\
\hline Greece & $1,176.50$ & 21.2 & 24.8 & 28.5 & 33.8 \\
\hline Spain & $6,645.60$ & 28.8 & n.d. & 37.8 & 41.5 \\
\hline France & $8,870.8$ & 25.8 & 29.3 & 33.9 & n.d. \\
\hline Croatia & 336.9 & n.d. & 20.2 & 23.4 & 25.8 \\
\hline Italy & $4,340.40$ & 13.0 & 15.5 & 18.3 & 20.3 \\
\hline Cyprus & 152.1 & 29.4 & 32.3 & 38.6 & 43.7 \\
\hline Latvia & 301.8 & 22.5 & 24.3 & 32.1 & 36.7 \\
\hline Lithuania & 505.3 & 48.6 & 30.9 & 41.1 & 42.4 \\
\hline Luxembourg & 102.5 & 21.9 & 31.2 & 39.0 & 45.6 \\
\hline Hungary & $1,017.50$ & 18.6 & 22.0 & 25.1 & 27.4 \\
\hline Malta & 38.6 & 8.7 & 17.1 & 20.6 & 25.4 \\
\hline Netherlands & $2,673.40$ & 28.1 & 34.0 & n.d. & 37.8 \\
\hline Austria & 857.0 & 17.4 & 20.9 & 22.0 & n.d. \\
\hline Poland & $4,675.90$ & 15.1 & 22.6 & n.d. & 32.4 \\
\hline Portugal & 920.6 & 10.3 & 14.4 & 17.5 & 22.0 \\
\hline Romania & $1,647.30$ & 9.7 & 13.4 & 16.7 & 19.1 \\
\hline Slovenia & 280.7 & 18.9 & 23.7 & 28.3 & 33.3 \\
\hline Slovakia & 503.7 & 13.6 & 17.6 & 20.9 & 23.1 \\
\hline Finland & 991.8 & 37.0 & 38.9 & 42.8 & 45.3 \\
\hline Sweden & $1,666.90$ & 32.1 & n.d. & 36.7 & 39.7 \\
\hline United Kingdom & $11,268.80$ & 28.7 & 32.9 & 39.1 & 43.1 \\
\hline $\begin{array}{c}\text { European Union } \\
\text { ( } 28 \text { countries) }\end{array}$ & $66,169.80$ & n.d. & 26.8 & 30.5 & 33.4 \\
\hline
\end{tabular}




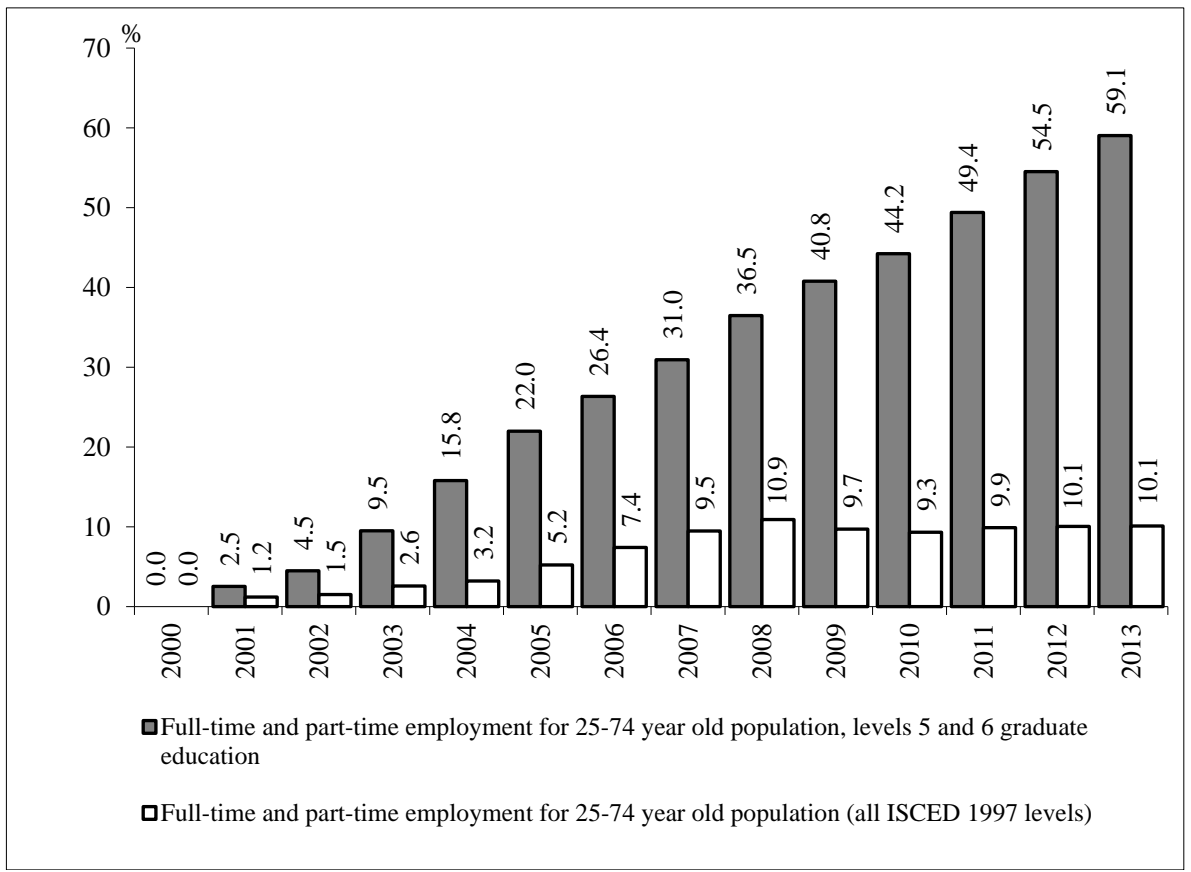

Figure 3 Relative change of the Full-time and part-time employment of 25-74 years old, total (all ISCED, 1997) and for category 5 and 6 levels of education in the EU countries (without Croatia) in the period 2000 to 2013 (+ / - in\% compared with 2000)

(Source: Adapted from Eurostat)

So, for a total of 14 countries for which we have full data in 20 is detected the existence of a specific association between two indicators evolutions, thereby possibly confirming that the expansion technology was one factor among others that made possible the continuation of education for the category of employed people.

Table 4 Dynamics of share of households with Internet access and share of fulltime and part-time employment with higher education in total employed population of 25-74 years old in 2013 compared with 2005 (\%)

\begin{tabular}{|lcc|}
\hline Countries & $\begin{array}{c}\text { Dynamics of share of } \\
\text { households with } \\
\text { Internet access }\end{array}$ & $\begin{array}{c}\text { Dynamics of share of employed } \\
\text { population with higher } \\
\text { education in total employed } \\
\text { population of 25-74 years old }\end{array}$ \\
\hline Belgium & 160.0 & 111.7 \\
\hline Bulgaria & n.d. & 115.2 \\
\hline Czech Republic & 384.2 & 149.6 \\
\hline Denmark & 124.0 & 103.2 \\
\hline Germany & 141.9 & 110.2 \\
\hline Estonia & 205.1 & 0.0 \\
\hline Ireland & 174.5 & 142.1 \\
\hline Greece & 254.5 & 136.1 \\
\hline Spain & 194.4 & n.d. \\
\hline Croatia & n.d. & n.d. \\
\hline France & n.d. & \\
\hline
\end{tabular}




\begin{tabular}{|lcc|}
\hline Italy & 176.9 & 130.6 \\
\hline Cyprus & 203.1 & 135.3 \\
\hline Latvia & 232.3 & 150.7 \\
\hline Lithuania & 406.3 & 137.2 \\
\hline Luxembourg & 144.6 & 145.9 \\
\hline Hungary & 322.7 & 124.5 \\
\hline Malta & 192.7 & 148.7 \\
\hline Netherlands & 121.8 & 111.0 \\
\hline Austria & 172.3 & 0.0 \\
\hline Poland & 240.0 & 143.4 \\
\hline Portugal & 200.0 & 152.9 \\
\hline Romania & n.d. & 142.2 \\
\hline Slovenia & 158.3 & 140.6 \\
\hline Slovakia & 339.1 & 131.1 \\
\hline Finland & 164.8 & 116.2 \\
\hline Sweden & 127.4 & 131.1 \\
\hline United Kingdom & 146.7 & 124.6 \\
\hline $\begin{array}{l}\text { European Union (without } \\
\text { Croatia) }\end{array}$ & 164.5 & \\
\hline
\end{tabular}

n.d. - no data

(Source: Adapted from Eurostat)

After all the assessments, we can say that the impact of information technology on the educational system and the dynamics of absorption of the adult population in lifelong learning will see the same trend in the near future, resulting in changes in all associated activities: research, teaching and learning, organization, organization and operating framework, legislation etc.

Regarding the evolution of the number of employed adults in lifelong learning, we tend to think that we will see a relative stagnation in the developing states. For example, in Romania we expect a reduction in the number of adults that return to formal learning system, such as distance learning, as a result of strictly objective factors: the impact of economic crisis on living standards and the purchasing power, increased tuition taxes in distance learning programs, low labor demand in large and very large organizations etc.

\section{References}

Aspin, D. N., Chapman, J. D. (2000), Lifelong learning: concepts and conceptions. International Journal of Lifelong Education, 19(1), 2-19.

Bates, A.W. (1999), Managing Technological Change: Strategies for Academic Leaders, San-Francisco, Jossey Bass.

Bates, A.W. (2001), National Strategies for E-learning in Post-secondary Education and Training, Paris, International Institute for Educational Planning, UNESCO.

Bell, R. Tight, M. (1993), Open Universities: A British Tradition, Buckingham, The Society of Research into Higher Education \& The Open University Press.

Bentley, T. (1998), Learning beyond the classroom: education for a changing world. London, Routledge.

Candy, P. (1991), Self-Direction for Lifelong Learning: A Comprehensive Guide to Theory and Practice, Jossey-Bass, San Francisco, California.

Council Of The European Union (2009), Council Conclusion on a strategic framework for European cooperation in education and training ET 2020, 
2941th Education, Youth and Culture Council meeting, Brussels, 12 may, 2009.

EC (2000), Memorandum on Lifelong Learning, Commission of European Communities, Brussels.

European Commission, EUROSTAT, available at http://epp.eurostat.ec.europa.eu.

Fischer, G. (2001), Lifelong Learning and its support with new media, International Encyclopedia of Social and Behavioral Sciences, No 41, retrieved June 7, 2007, from, http://13d.cs.colorado.edu/ gerhard/papers/iesbs2001.pdf.

Garrison, D.R. (1999), Will distance education disappear in distance studies? A reaction, Journal of Distance Education, 14(2), 10-13.

Jiusto, S., DiBiasio, D. (2006), Experiential Learning Environements: Do they Prepare Our Students to be self directed, Life Long Learnings?, Journal of Engineering Education, july, 195-204.

Klamma, R., Chatti, M.A., Duval, E., Hummel, H., Hvannberg, E.H., Kravcik, M., Law, E., Naeve, A., Scott, P. (2007), Social Software for Life-long Learning, Educational Technology \& Societ, 10 (3), 72-83.

Knapper C., Cropley A.J. (2000), Lifelong learning in higher education, London, Kogan Page.

Köse U. (2010), A blended learningnext term model supported with Web 2.0 technologies, Procedia - Social and Behavioral Sciences, 2 (2), 2794-2802.

Institutul Naţional De Statistică, Tempo - Online time series (www.insse.ro).

Niper, S. (1989), Third generation distance learning and computer conferencing, in: Mason, R. and Kaye, A. (eds.), Mindweave: Communication, Computers and Distance Education, Oxford, Pergamon Press, 63-73.

Peters, O. (2001), Learning and Teaching in Distance Education: Analysis and Interpretations from an International Perspective London, Kogan Page.

Ryan, Y. (2002), Emerging Indicators of Success and Failure in Borderless Higher Education, London, The Observatory on Borderless Higher Education.

Sharples, M. (2000), The design of personal mobile technologies for lifelong learning, Computers and Education, 34, 177-193.

U.S. Department of Education (2002), A Profile of Participation in Distance Education: 1999-2000, Washington D.C., National Center for Educational Statistics. 